\title{
声帯癌の進展形式と治療方針について
}

\author{
佐藤武男・石井孚・内海重 光*
}

緒 言

臨床病理学的に眺めて, 声帯癌には 3 つの特徵がある。すなわち，1）殆ど男性の疾患である. との傾向は全ての喉頭癌についていえることであるが，特に声帯癌では97\%が男性である，2）早 期診断が行なわれば，放射線治療などの保存的治療が可能である。3) 臨床病理学的の像から眺め て，その進展速度が比較的緩徐であり，その進展形式には一定の型があるというととである.

本論文では以上の諸点を重視して, 声帯癌の早期䛦断とは何か. また声帯癌の進展の形式はどの 様に方向づけられているかを論じたいと思う.

\section{1. 声帯癌の臨床的な事項}

最近（1958～1965）取扱つた声帯癌は 127 例（声門 下原発 3 例を含む）であり，これは同期間に根治治療

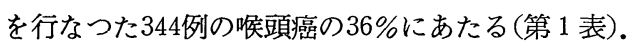

第 1 表 喉頭癌根治治療症例数（1958～65）

\begin{tabular}{l|r|c}
\hline & 例数 & $\%$ \\
\hline glottic, subglottic & 127 例 & $36 \%$ \\
supraglottic, marginal & 160 例 & $47 \%$ \\
transglottic & 57 例 & $17 \%$
\end{tabular}

これから，日本人喉頭癌は supraglottic，とくに喉頭前 庭部癌が一番多い様である。

声帯癌の性別については 127 例中，女性はわずか 4 例（3\%）であつて，全喉頭癌についての女性比率よ りも少い(第 2 表).

これは 男性声帯の 持つ形態的な大きさ， 質量，太
第 2 表 喉頭癌の性別 \%

\begin{tabular}{|c|c|c|}
\hline & 古 & 우 \\
\hline 全 喉 頭 癌 & $94 \%$ & $6 \%$ \\
\hline 声市 癌 & $97 \%$ & $3 \%$ \\
\hline
\end{tabular}

さ，声門下腔圧の大きさおよび男性性格としての多弁 性, 社会生活環境および生活態度, またタバコの刺激 などの相加，相乗作用のためと考えたい．

年令的な傾向は全喉頭癌患者における分布状態と殆 ぞ同一であつた(第 3 表).

第 3 表 喉頭癌の年令分布 \%

\begin{tabular}{c|c|c|c|c|c|c}
\hline 年令 & $30 \sim$ & $40 \sim$ & $50 \sim$ & $60 \sim$ & $70 \sim$ & $80 \sim$ \\
\hline 全喉頭癌 & 1 & 5 & 30 & 47 & 15 & 2 \\
声 帯 癌 & 2 & 7 & 29 & 43 & 16 & 3
\end{tabular}

\section{2. 早期診断について}

声帯における受傷好発部 (locus minoris) は三部位 である。すすねわ，1）声帯膜部の中央，2）声帯軟骨 部声帯突起および前連合部である。

声帯癌については，その原発部位が何処であるかを 調べた。まず左右差について検討したが，殆ど50：50 で差はなく，前連合附近に原発したものは 2 例に過ぎ なかつたそその他は全て声帯に始まり，特に声帯膜部 の中央が原発部位であつた。これは声帯ポリープの好 発部位と一致する。
つぎに声帯を前額面に切片を作り，発癌部位を検討 した(第 1 図). Ca. in situ は全て声帯有離縁の上半分 の扁平上皮部より発生する，とくに線毛上皮と扁平上 皮との移行部 (linea arcuata sup., inf.) が発癌部位々 は考えられなかつた。しかし上皮細胞の悪性化につれ て，粘膜固有層が反応し，特有の間質反応を起こすこ とは興味がある。

早期診断に関しては, 間接唉頭鏡像の判読が一番重 要である. 第 2 図は声帯膜様部中央部琚離縁より発生

$*$ 大阪大学医学部耳鼻咽喉科学教室（主任 : 内藤儶教授） 


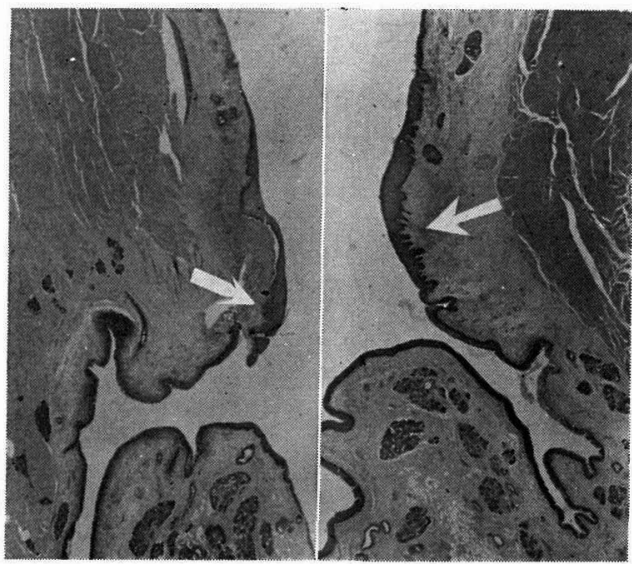

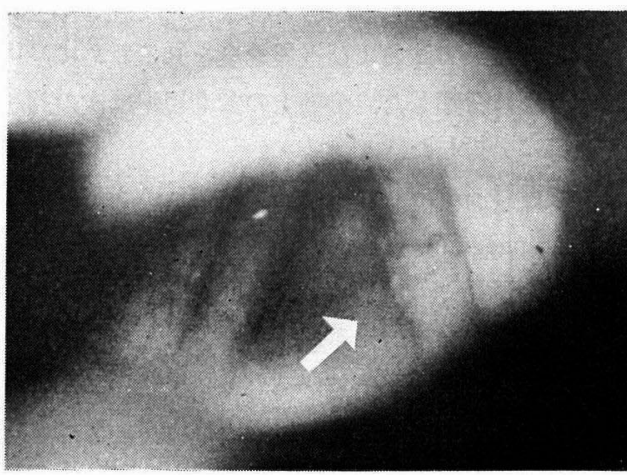

第 2 図 声帯癌初期像

第 1 図声帯癌初期像

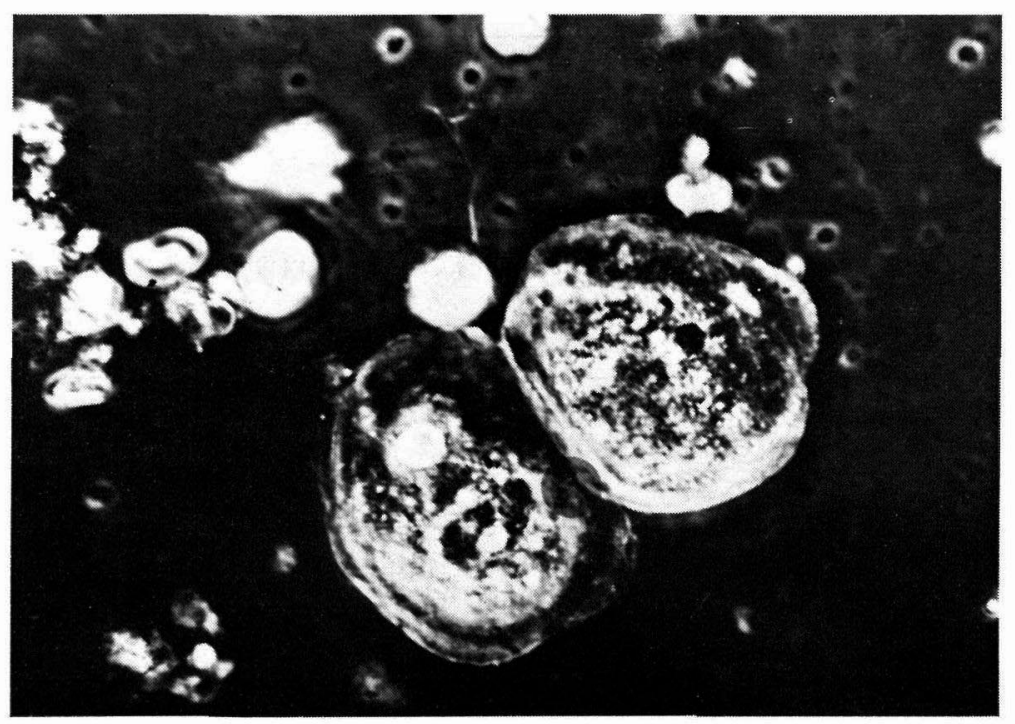

第 3 図塗擦標本の位相差顕微鏡像核優勢

した声带癌の所見であるが，周辺間質に特有の間質反 応（血管反応，浮腫など）を伴つている点に興味があ る.

最も確実な診断法は，声带有離縁にそつて平行に少 量の組織片を，発声時声帯内転とともに鉗除すること である。決して声帯有離縁に角度をもつて鉗除しては ならない。

また塗擦慓本の位相差顕微鏡による診断も可能であ り，診断の確実性を確めることはできる．細胞の異形 性，核優性，ミトーゼなどが認められればよい。
しかしレントダン診断 (tomogram, laryngogram) については，早期診断に関する限り，全く無力であつ た.これは進展症例の部位診断には有力であつた。

患者の嗄声発症時期については，問診には判然とし ないことが多い. 平常，声が悪いと述へる症例が多 く，慢性喉頭炎を基礎として発癌することが考えら れ，また風邪引きのあと嗄声が発症または増強すると 訴える者が多いことから，炎症は癌の進展に加速度を 加えることも考えられる. 


\section{3. 声帯癌の分類および進展形式について}

声帯癌の進展方法および進展速度を知るために，声 帯癌を 8 形に分類した. 分類上の参考規準は次の諸所 見を㛜密に分析した。

1. 喉頭鏡所見

2. laryngogram, tomogram

3. 手術所見

4. 喉頭剔出標本所見

5. 大切片病理標本所見

以上の所見を総合して，各分類の症例数，分布\%， 病歷期間とその進展範囲，国際分類法との対比を示し た(第 4 図). この分類法から声帯癌の進展形式とその 速度，さらには声帯癌の進展吕遅い事実，また早期診
断とは何処までをいうのか等がわかる.

分類した症例数は声門下原発 3 例を除く 124 例であ る.

I. 初期癌 14 例 $(11.0 \%)$

声帯癌の原発部位は前述したごとく，声帯の前 $1 / 3$ と中 $1 / 3$ の界面に多く，声帯有離縁に沿つている.声 帯振動における locus minoris の部位であり，この部 位に慢性の循環障害が起こり，しかも声帯の慢性カタ ル性炎を基盤として発癌するのであろう。この部の扁 平上皮の肥厚と脱落を繰り返えし，Reinkeの space も 相関して反応し癌化が起こるに違いない，本来ならば $2 \sim 3$ 層の上皮層が分裂増殖し Ca. in situ の形態を

\begin{tabular}{|c|c|c|c|c|c|c|}
\hline 分類名 & 喉頭鏡像 & 展開像 & & 症例数 $(\%)$ & 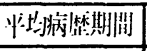 & |⿴囗大盽分類 \\
\hline I、初期癌 & & & 原発部位は膜部中央 & 14 例 $(11.0 \%)$ & 4 力月 & $\mathrm{T}_{1}$ \\
\hline $\begin{array}{c}\text { I、一賱限局形良) } \\
\text { 形 }\end{array}$ & & & $\begin{array}{l}\text { 声帯膜部全長、声帯突起に及 } \\
\text { ばす運動良好 }\end{array}$ & 44 例 $(34.6 \%)$ & 6 力月 & $\mathrm{T}_{1}$ \\
\hline I、前連合形 & & & 肉芽様增殖 & 2 例 $(1.5 \%)$ & 12 力月 & $\mathrm{T}_{2}$ \\
\hline N、前方進展形 & & & 両側声带に及ぶ、運動发好 & 9 例 $(7.0 \%)$ & 1.5年: & $\mathrm{T}_{2}$ \\
\hline $\begin{aligned} \text { V、一側限局形 } \\
\text { (運動不良) }\end{aligned}$ & & & 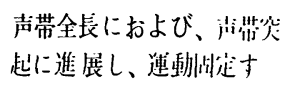 & 0 例 (0\%) & & $\mathrm{T}_{2}$ \\
\hline V、下方進展形 & & & 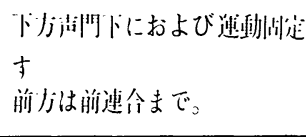 & 31 侧 $(24.4 \%)$ & 2件: & $\mathrm{T}_{3}$ \\
\hline U、汕側進展形 & & & 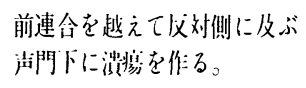 & 14 例 $(11.0 \%)$ & 2.5位: & $\mathrm{T}_{3-4}$ \\
\hline V、晚期癌 & & & 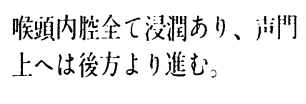 & 10 例 $(7.8 \%)$ & 2.5作以上 & $\mathrm{T}_{3-4}$ \\
\hline
\end{tabular}

第 4 図声帯癌 分類 表 
取り，さらに基礎膜下組織に延伸性増殖を関始する. lig. vocale への癌発育形態は延伸形をとる.この部で 止まり，さらに前後にとくに前方に進展の始める時期 までを初期癌と名付けた。この時期の平均病歷は 4 力 月であつた。

II. 一側限局形 (声帯膜部 Pars intermembranacea 全長にわたり進展，運動は良好）44例 (34.6\%)

進展が前後に進み，前方は前連合まで，後方は声带 突起までの時期で，披裂軟骨への浸潤はなく，声帯運 動は良好である。深部へは声帯勒帯を越え，声帯筋を 圧迫し変性せしめる。その発育形態は延伸形である。 進展に抵抗する部位は前連合黄玟部, 披裂軟骨膜, 声

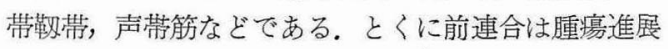
に強く抵抗する.

この時期の病歴は平均 6 力月である。半年過ぎると これらの抵抗部を突破して，前・後・下方に進む。

I，正期を合わせて46\%になり，この時期までが声 帯癌の大半を占めている。この間を早期診断と考えた い. 㖽声を訴えて半年までに診断されれば，放射線治 療で根治可能である。

\section{III. 前連合形 2 例 $(1.5 \%)$}

前連合部上下に限局した形で，一見肉芽様増殖を示 すものがあり，転移も広範囲で，臨床的に悪性であ る.しかし発生頻度は極めて稀である。平均病歴は1 年である.

\section{IV. 前方進展形 9 例 $(7.0 \%)$}

一側声帯加ら前連合を越え，他側声帯に進んでいる 形であり, 主として声門前方に位置するため, 声門運 動は残存している。この例は比較的少なく, 平均病歴 は1.5年である.

\section{V. 一側限局形，運動固定}

声带全長に及び披裂軟骨も侵され運動固定している 場合で，これは国際分類 $T_{2}$ にあたる。しかしながら 私共の検索ではこの形は存在せず，外見上この形に見 えても，必ず下方 subglottic 一進展している.すなわ ち $\mathrm{T}_{3}$ となつている. したがつて国際分類上 $\mathrm{T}_{2}$ の存 在を否定したいと思う。今後の改訂が望ましい.

\section{VI. 下方進展形 31例 $(24.4 \%)$}

前述したごとく，声率運動固定があれば必ず subglottic $\left(\mathrm{T}_{3}\right)$ への進展がある. 症例数も比較的多く, glottic の最も代表的な形である. 前方は前連合で止ま り, 下方進展は粘膜下に相当進展している. 平均病歴 は2 年である。

VII. 両側進展形 14例 $(11.0 \%)$
前連合を越えて，他側声帯に及び，さらに後方に進 んだ形である. 多くは声門下に潰瘍を形成する。平均 病歷は2.5年である。呼吸困難を伴うことが多い.

VIII. 晚期形 10 例 $(7.8 \%)$

喉頭内空を全て浸潤する.声門上へは主として後方 より上に進展する. 両側声帯運動は障害され, 呼吸困 難を来す，平均病歴は2.5年以上過ぎている。

以上の分類からもわかる様に，声帯癌の進展はその 解剖学的な特殊性に保護されて，各所に barrier があ り，比較的緩徐である．私共の経験では最高 7 年の経 過を経て呼吸困難を来し，気管切開を行ない，全剔出 後健在している症例を持つている. 第 5 図はその喉頭 剔出標本である.

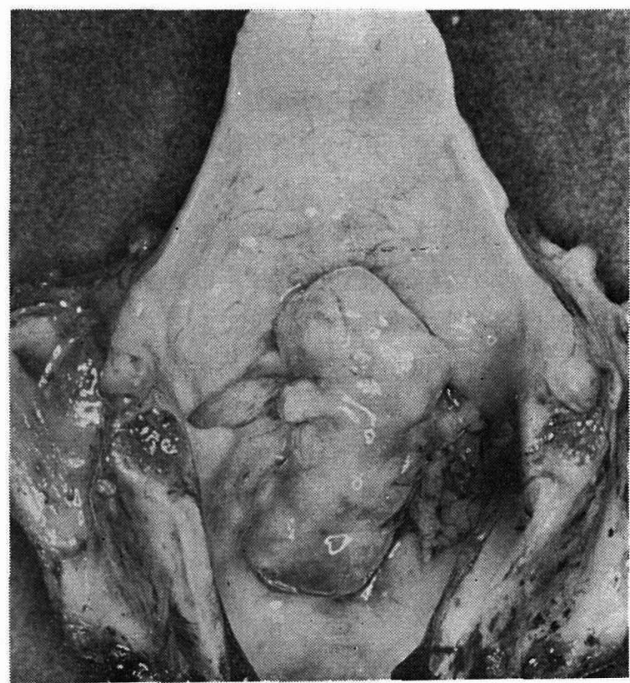

第 5 図 発癌以来 7 年を経過した喉頭癌標本

つぎに呼吸困難を訴えて救急入院を行ない，気管切 開を施行した症例は 9 例である(符 4 表).

第 4 表 気管切開例の分類と病歴

\begin{tabular}{c|c|c}
\hline 分 類 & 例数 & 病歴 \\
\hline VI 下方進 展 形 & 3 & 3 年 \\
VII 雨側進 展 形 & 4 & 4 年 \\
VII 晚 期 形 & 2 & 5 年
\end{tabular}

いずれにしろ，治療をしなければ，声帯癌は $3 〜 5$ 年の間に呼吸困難で死亡することを示している.

以上の分類所見および病歴から，声帯癌の進展形式 を絵括すると，つぎの順となる。

1. 原発部は主として，声帯膜部中央で，扁平上皮 
有離縁の上方笴りである．増殖形式に 2 種類あつて， 基礎膜下に漫潤する形と，喉頭内腔に乳頭状に突出す る形がある。

2. 声帯縁に沿つて前後に進展し，特に前方に進 む。 barrier が 2 力所あつて，一つは前連合，一つは披 裂軟骨膜である。声帯膜部に限局している間は 6 力月 までである。

3. 半年を越えると前方の barrier である前連合を 越して進む可能性がある．他側声帯では前方より後方 に進む。

4. 披裂軟骨を侵す前に，主として下方への進展を 開始する．逆に下方進展なしに披裂軟骨を侵すことは ない. subglottic は粘膜下組織が比較的疎であるので， 腫場の進展は他の部位に比べて容易である．多くは粘 膜下進展の形をとり，特徴的なことは腫場尖端は増殖 反応を呈し，かつ簇出傾向が著明であることである．

5. 声門下に多くは広い潰瘍を形成する。

6. 深部へも深く入り，まず lig. vocale を侵し， 筋層を圧排し，さらに筋線維を変性せしめ結合織に置 換する.したがつて，その間質反応は増殖性炎の形を とる. 腫瘍発育形式は延伸発育形である。軟骨膜に達 すると，この部で抵抗を受け，その方向は下方に向か う.

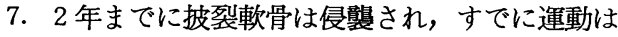
固定してしまう。さらに披裂部を粘膜下に進展し，こ

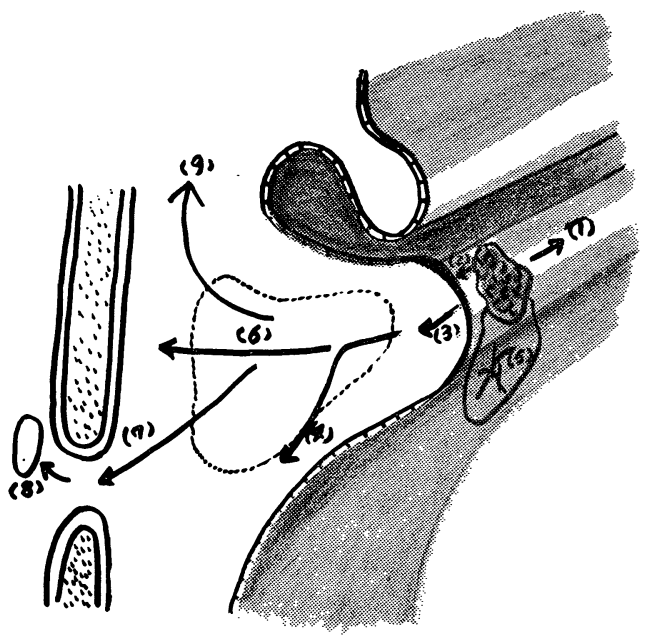

（1）前方進展，（2）後方進展，（3）樑部延伸発育,

(4) 下方粘膜下進展， (5) 声門下潰瘍， (6) 筋層内 進展，(7) 輪状甲状膜進展，(8) 喉頭前リンバ節転 移，(9) 上方進展（後方形をとる）

第 6 図声帯癌進展形式
の部の浮腫性腫脹は特徴的所見である.

8. 2 年過ぎると前連合も侵され，両側進展形とな る.

9. 2 年半過ぎると上方進展が始まり, transglottic の形をとる。この進展経過は主として披裂軟骨の上 方, 声門後部を通り粘膜下組織の疎な部位を進んで上 方に向い，急に速度を増す。

以上の進展形式を図示すると第 6 図のごとくなる. 喉頭癌 130 例の大切片標本による病理組織学的検討 を行なつた結果は第 5 表のごとくである．声帯癌は全 て扁平上皮癌であつた。

第 5 表 喉頭癌と組織覀性度との関係（）内\%

\begin{tabular}{l|r|r|r|r}
\hline \multirow{2}{*}{ 分 類 } & \multicolumn{3}{|c|}{ 組織悪性度 } & \multirow{2}{*}{ 計 } \\
\cline { 2 - 3 } & \multicolumn{1}{|c|}{ I } & \multicolumn{1}{|c|}{ II } & III & \\
\hline glottic & $11(61)$ & $7(39)$ & $0(0)$ & 18 \\
subglottic & $4(31)$ & $8(62)$ & $1(7)$ & 13 \\
supraglottic & $7(23)$ & $20(65)$ & $4(13)$ & 31 \\
marginal & $11(28)$ & $17(44)$ & $11(28)$ & 39 \\
transglottic & $9(3)$ & $14(48)$ & $6(21)$ & 29 \\
\hline \multicolumn{1}{c|}{ 計 } & $42(32)$ & $66(51)$ & $22(17)$ & 130
\end{tabular}

組織悪性度とは50Xにて観察し，I度は癌真珠を全 視野に認め，細胞，核の異形性の軽度なもの，II度は 癌真珠を一部視野に認め，細胞，核の異形性が中等度 のもの，III度は殆どの視野に癌真珠の認められないも ので，細胞の核の異形性高度のものに分類した。

この表からも明らかなごとく，声帯癌はI， II 度が 殆どであつて，組織悪性度は他部位に比して低いこと を示している。

つぎに腫瘍発育形を国際分類別に眺めたのが第 6 表 である．声帯癌は延伸発育形をとることが多く，下方 進展すると続発性簇出形をとる.

第 6 表 喉頭癌と腫瘍発育形との関係

\begin{tabular}{l|r|r|r|r}
\hline \multicolumn{1}{c|}{ 分類 } & $\begin{array}{c}\text { 延 伸 } \\
\text { 発育形 }\end{array}$ & $\begin{array}{l}\text { 肥 大 } \\
\text { 発育形 }\end{array}$ & \multicolumn{2}{|c|}{ 簇出発育形 } \\
\cline { 3 - 5 } & 7 & 3 & 1 & 7 \\
glottic & 7 & 0 & 1 & 10 \\
subglottic & 2 & 5 & 2 & 20 \\
supraglottic & 4 & 続発性 \\
marginal & 5 & 6 & 5 & 23 \\
transglottic & 3 & 5 & 5 & 16 \\
\hline \multicolumn{1}{c|}{ 計 } & 21 & 19 & 14 & 76
\end{tabular}


第 7 表 声帯癌の治療方針

\begin{tabular}{|c|c|c|c|}
\hline \multirow{2}{*}{ 分 類 } & \multicolumn{3}{|c|}{ 優先する治療方法の順序 } \\
\hline & $\mathrm{I}$ & II & III \\
\hline I 初期癌 & & & \\
\hline 1）角化著明及び乳頭状増殖 & cordectomy & radiation & \\
\hline 2） 角化普通 & radiation & cordectomy & \\
\hline II 一側限局形( 運動良) & radiation & cordectomy & laryngectomy \\
\hline III 前連合形 & radiation & laryngectomy & neck dissection \\
\hline IV 前方進展形 & radiation & laryngectomy & neck dissection \\
\hline VI 下方進展形 & $\begin{array}{l}\text { vertical } \\
\text { partial } \\
\text { laryngectomy }\end{array}$ & laryngectomy & neck dissection \\
\hline VII 両側進展形 & laryngectomy & neck dissection & \\
\hline VIII 晚期形 & laryngectomy & neck dissection & \\
\hline
\end{tabular}

第 8 表 声帯癌の転移と予後

\begin{tabular}{|c|c|c|c|c|c|}
\hline & 分 類 & リンパ節転移 (例数) & 転移部位 & 転移率 & 死亡例数 \\
\hline I & 初 期 癌 & 0 & & & \\
\hline II & 一側限局形 & 0 & & & \\
\hline III & 前連合形 & 1 & $\mathrm{DEF}, 1$ & $1 / 2 \quad(50 \%)$ & \\
\hline IV & 前方進展形 & 2 & $\mathrm{D}, 1 \quad \mathrm{E}, 1$ & $2 / 9 \quad(22 \%)$ & \\
\hline VI & 下方進展形 & 11 & $\mathrm{D}, 10 \mathrm{E}, 1$ & $11 / 31(35 \%)$ & 2 \\
\hline VII & 両側進展形 & 6 & $\mathrm{D}, 4$ B, 1 BE, 1 & $6 / 14(43 \%)$ & 1 \\
\hline पIII & 晚 期 形 & 8 & $\mathrm{D}, 5 \mathrm{BE}, 1 \quad \mathrm{E}, 2$ & $8 / 10(80 \%)$ & 3 \\
\hline
\end{tabular}

\section{4. 治療方針および転移と予後について}

声帯癌の臨床病理学的な検討の結果, 私共の現在の 治療指針は第 7 表のごとくなる.

声帯癌の治療に関しては，音声を保存しようとする 保守的な面と，癌治療本来の姿である徹底的手術とが 適当に結合しているといえるであろう。いずれも根治 を目的としていることは当然である．したがつて進展 分類を診断する上はあやまりのない様，レントゲン断 層写真を参考とすべきである.

生命保存の意味では, radiation \& partial laryngectomy にも自ら適応の限界があり，進展形には laryngectomy が優先されるべきである.

つぎに転移と予後の問題について述べる、一般に頭 頸部腫瘍の転移には一定の型と順序がある. 同じ喉頭 癌についても，その様式は異なるので，第 7 図のごと く頸部地図を作り，転移の様相を調べたのが第 8 表で ある。

初期癌および一側限局形では転移は認められない.

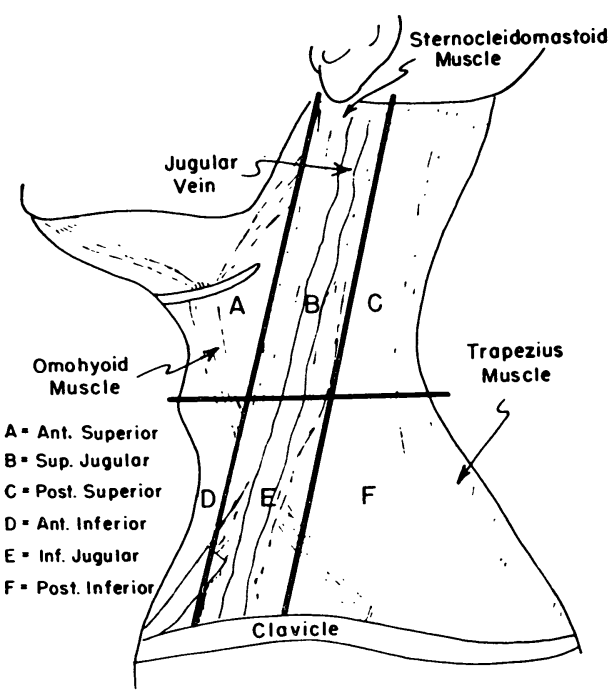

第 7 図 頸部分画地図（McGavran） 
前連合形では 1 例に D.E.F. 地区に広いリンパ節転移 を認めた。前連合形には悪性なものが含まれている. 前方進展形は D.E. 地区に 1 例づつ, 下方進展形の転 移は主として喉頭前リンパ節である。両側進展形およ び晚期形には B.E. 地区の転移が現われてくるのが興
味がある。これは喉頭癌の上方進展を意味するのであ ろう。

転移率は進展の進むにつれて増加している，予後も VI, VII, VII 形に悪くなつている.

結局治癒率は121/127，95\%の成績であつた。

\section{5. 結 語}

声帯癌127例を臨床病理学的に検討して，つぎの結論を得るととができた.

1. 声帯癌は慢性カタル性炎症を基盤として発生するように思える，風邪などの炎症は癌進展に 加速度を加える。

2. 男性に97\%であつた。乙れは喉頭の形態学的な大きさ，肺活量，声門下圧の大きさなどによ る他，患者の性格，態度，社会環境なども大きく働くすのと考える.

3. 発癌部位は声帯膜部有離縁の上方寄りで中央に多い.

4. 早期診断は嗄声発症後半年までである.

5. 声帯癌は一定の進展形式をとる。進展に抵抗する部位は前連合と披裂部軟骨膜である．声門 下腔への進展は容易であり, 粘膜下に進む。

6. 進展形式により分類を試み， 7 形式の分類を行なつた。国際分類でいう $T_{2}$ の内，一側声帯 に限局し，運動固定の形は存在しなかつた．との際には必ず subglottic への進展が認められる．す なわち $\mathrm{T}_{3}$ である。

7. 前連合形には悪性のむのがある.

8. 臨床病理学的に腫瘍発育形式は延伸形をとる．下方への進展は続発性簇出形である.

9. 治療は進展の時期により最む良い方法を選ぶべきである.

10. 治療成績は95\%であつた。

恩師内藤儶教授のご指導，ご校閲を謝す。

\section{文献}

1）佐藤武男 : 喉頭癌の治療シンポシュウム別冊, (昭38)

2) 北村 武：喉頭部分切除による喉頭癌の治療. 耳喉, 36:7；585（昭39）

3）広戸幾一郎：喉頭部分切除術，耳鼻臨床， 58 : $4 ; 178$ (昭 40$)$

4）黒住静之：Vertical Partial Laryngectomy, 気食 会報, $16: 6$ (昭 40$)$

5）佐藤武男，他：声帯癌放射線治療失敗例の臨床
病理学的検討. 日耳鼻, 69:10 (昭 41)

6) McGavran, M.H. et al : The Incidence of Cervical Lymph Node Metastases From Epidermoid Caricnoma of the Larynx and Their Relationship to Certain Characteristics of the Primary Tumor : Cancer $14: 7$; 55, 1961.

7) Wilson, C.P. : Treatment of Intrinsic Carcinoma of the Larynx, J. Laryng., 75 : 9 ; 785, 1961. 